\title{
Cotton Production Trends in Pakistan: An Integrative Review
}

Khalid Mehmood Ch${ }^{1}$. Saleem Ashraf ${ }^{1^{*}}$, Ijaz Ashraf ${ }^{1}$

${ }^{1}$ Institute of Agricultural Extension, Education and Rural Development, University of Agriculture Faisalabad, Pakistan.

ART ICLE INFO

\section{Article History}

Received: August 24, 2021

Revised: November 30, 2021

Accepted: December 18, 2021

\section{Keywords}

Climate Change

Decline

Change

Textile Industry

Constraints
A B S T R A C T

Cotton is regarded as a cash crop in Pakistan and the country is ranked $5^{\text {th }}$ in terms of production and $5^{\text {th }}$ importer in the world as well. Cotton production in Pakistan is under huge pressure and it's continuously declining over the period. This review aimed at exploring the different reasons for the cotton production decline. This review comprises two major sections. In the first section, percentage change in area, production and yield of cotton in Punjab, Sindh and Pakistan is calculated from 19902020. This analysis indicated a drastic decline in area, production and the average yield of cotton in the country. In the second section, previously published literature is consolidated to explore the different constraints causing change in the area, production and average yield of cotton. The major constraints causing the sweeping decline included environmental constraints, climate change, water-related constraints, agronomic constraints and socio-economic related constraints. This study concludes that cotton crop decline is not in favor of cotton associated industry, farming groups and national economy and it is much needed to bring reforms for the revival of cotton crop. This study urges further research on exploring the reasons that are compelling farmers to reduce the cotton area, quitting cotton cultivation or switching to other crops.

Corresponding Author: Saleem Ashraf

Email: saleem1828@gmail.com

(C) The Author(s) 2021.

\section{INTRODUCTION}

Pakistan is regarded as 5th largest cotton producer after China, India, United States and Brazil and as well as 5th leading importer of the cotton in the world after China, Bangladesh, Vietnam and Turkey. In Pakistan, cotton enjoys the status of industrial cash crop and therefore is helpful in supporting the rual livelihoods and national economy as well. Cotton is the chief source of input to textile sector, that is the largest industrial sector of Pakistan absorbing $40 \%$ of total labor force (GOP, 2019). Cotton and related textile products not only earn foreign exchange but are also the protruding source of livelihood for the millions of farmers. Around 1.6 million farmers in Pakistan were cotton growers cultivating cotton on $15 \%$ of total cropped area in Pakistan (USDA, 2019).

Cotton has a tremendous role in progress of rural sector in Pakistan. Because of universal linkages, cotton has a dominating scope towards agricultural development and posing significant impacts on the overall economic development in Pakistan. During 2018-19, cotton added $4.5 \%$ to agriculture value addition (GOP, 2019). Cotton is promising source of fiber around the world and cottonseed offers edible oil to meet the $64 \%$ of the nation's demand for edible oil (Abid et al., 2011). In addition, the cotton seed byproduct commonly known as seed cake is considered as valuable animals' feed.

Cotton, being the source of livelihood and reflective contributor to the national economy, had emerged as a topic of national interest as number of researchers of national and international cadre have a keen interest on researching cotton and future developments in cotton sector. For instance, Ashraf et al. (2018) forecasted the 
area under cotton cultivation, production and yield in Punjab province of Pakistan by using the data from 19902017. Their results indicated that area under cotton cultivation and yield of cotton decreased gradually. Whereas this study further highlighted that average yield will continue to decline in Punjab till 2025. There are few more studies on cotton crop such as Ali et al. (2013); Ali et al. (2015); Tunio et al. (2016); Shuli et al. (2018) provides important insight into current and future situation of cotton crop in Punjab province in particular. These studies had an agreement that the cotton crop is facing a decline and synergistic work is much needed for its revival.

Plenty of studies focusing on current and future trends of cotton have been conducted in Pakistan. Most of these studies were based on time series data and some were based on primary data collected from the specific study area and small sample size. Despite of conductance of these studies, hardly an in-depth scenario emerged in order to consolidate the ground reasons behind the cotton crop failure in Pakistan. Thus, there was a need for an extensive literature review to underpin and consolidate the different factors contributing to the failure of cotton crop. This review is conducted to bridge the research gap and aims to give readers a consolidated overview on different factors impeding the cotton crop production. This integrative review comprises of major two sections. The first section is to calculate the change in area, production and yield of the cotton in Punjab province, Sindh province and Pakistan, respectively. The second part is based on the critical examination of the literature review to explore the reasons behind this change in area, production and average yield. Environmental, soil fertility, salinity, waterlogging, climate change, agronomic factors, water management related and socio-economic related constraints are critically examined to end up with the conclusions.

Change in Area, production and Yield of Cotton crop In this section data regarding area, production and yield of cotton in Punjab, Sindh and Pakistan were collected from different sources like Pakistan Bureau of Statistics from 1990 to 2020. Considering the data, percentage change in an area, production and yield of cotton was calculated. The data in this regard are tabulated in
Tables 1, 2 and 3 .

\section{Change in area of cotton crop}

Table 1. indicates that from 1990-2005 the cotton area observed a continuous increase in Punjab province and in 2005 cotton cultivation was second highest at 2518 000 hectares after reaching at 2526000 hectares during 2002. After 2005, the area under cotton cultivation continues to fall drastically showing a significant change. From the year 2016-17 to 2019-20 the change in areas was negative implying a major change in areas under cotton cultivation. In those areas, cotton was started to be replaced by alternate crops like sugarcane and maize in the Punjab province. As compared to Punjab, there was a minimum change in area under cotton cultivation in Sindh. However, as for as Pakistan is concerned, change in area of cotton cultivation is negative from the year 2016-17 to 2019-20. This confirms that area under cotton cultivation in the Punjab and Pakistan is decreasing gradually.

\section{Change in production of cotton crop}

Table 2. shows that from the year 1990 to 2020, the production of cotton in Punjab showed negative growth. This implies the obtained production was less than the potential and set target. From 2015-16, cotton crop in Punjab province witnessed a dominating drastic decline in production. It might be said that with the reduction in area under cultivation the production was also decreased. The Sindh province showed promising improvement in production of cotton. Across the Pakistan, production faced a decline as well.

\section{Change in average yield of cotton crop}

Table 3. shows that Punjab province observed a more decline in average yield of cotton as compared to Sindh province where average yield was higher. In Punjab province, for most of the years the change in average yield was negative. Especially from the year 2015, the change in yield was negative indicating a serious decline. During 2015, the average yield in Punjab was recorded at $481 \mathrm{Kg} /$ hectare whereas in Sindh average yield was recorded on $952 \mathrm{~kg} /$ hectare in the same year. As for as national average was concerned, 581 $\mathrm{Kg} /$ hectare was recorded in 2015. Afterwards, a fluctuation ca be observed in national average yield of cotton. 
Table 1. Change in cotton area under cultivation in Punjab, Sindh and Pakistan from 1990-2020.

\begin{tabular}{|c|c|c|c|c|c|c|}
\hline \multirow[b]{2}{*}{ Year } & \multicolumn{2}{|c|}{ Punjab province } & \multicolumn{2}{|c|}{ Sindh province } & \multicolumn{2}{|c|}{ Pakistan } \\
\hline & Area & $\%$ Change & Area & $\%$ Change & Area & $\%$ Change \\
\hline $1990-1991$ & 2124 & - & 537 & - & 2662 & - \\
\hline 1991-1992 & 2287 & 7.67 & 548 & 2.05 & 2836 & 6.54 \\
\hline $1992-1993$ & 2438 & 14.78 & 397 & -26.07 & 2835 & 6.50 \\
\hline 1993-1994 & 2249 & 5.89 & 555 & 3.35 & 2804 & 5.33 \\
\hline 1994-1995 & 2244 & 5.65 & 406 & -24.39 & 2653 & -0.34 \\
\hline $1995-1996$ & 2463 & 15.96 & 529 & -1.49 & 2997 & 12.58 \\
\hline 1996-1997 & 2540 & 19.59 & 601 & 11.92 & 3148 & 18.26 \\
\hline 1997-1998 & 2348 & 10.55 & 600 & 11.73 & - & 0.00 \\
\hline 1998-1999 & 2283 & 7.49 & 630 & 17.32 & - & 0.00 \\
\hline $1999-2000$ & 2329 & 9.65 & 634 & 18.06 & 2983 & 12.06 \\
\hline $2000-2001$ & 2386 & 12.34 & 524 & -2.42 & 2927 & 9.95 \\
\hline $2001-2002$ & 2526 & 18.93 & 547 & 1.86 & 3115 & 17.02 \\
\hline $2002-2003$ & 2208 & 3.95 & 543 & 1.12 & 2794 & 4.96 \\
\hline $2003-2004$ & 2387 & 12.38 & 561 & 4.47 & 2989 & 12.28 \\
\hline 2004-2005 & 2518 & 18.55 & 635 & 18.25 & 3192 & 19.91 \\
\hline $2005-2006$ & 2426 & 14.22 & 637 & 18.62 & 3103 & 16.57 \\
\hline $2006-2007$ & 2463 & 15.96 & 570 & 6.15 & 3075 & 15.51 \\
\hline $2007-2008$ & 2425 & 14.17 & 607 & 13.04 & 3054 & 14.73 \\
\hline 2008-2009 & 2224 & 4.71 & 562 & 4.66 & 2821 & 5.97 \\
\hline $2009-2010$ & 2436 & 14.69 & 635 & 18.25 & 3106 & 16.68 \\
\hline $2010-2011$ & 2201 & 3.63 & 457 & -14.90 & 2689 & 1.01 \\
\hline 2011-2012 & 2534 & 19.30 & 259 & -51.77 & 2835 & 6.50 \\
\hline $2012-2013$ & 2308 & 8.66 & 530 & -1.30 & 2878 & 8.11 \\
\hline $2013-2014$ & 2199 & 3.53 & 568 & 5.77 & 2806 & 5.41 \\
\hline 2014-2015 & 2323 & 9.37 & 596 & 10.99 & 2963 & 11.31 \\
\hline $2015-2016$ & 2243 & 5.60 & 621 & 15.64 & 2902 & 9.02 \\
\hline $2016-2017$ & 1815 & -14.55 & 637 & 18.62 & 2489 & -6.50 \\
\hline 2017-2018 & 2053 & -3.34 & 612 & 13.97 & 2701 & 1.47 \\
\hline $2018-2019$ & 1888 & -11.11 & 448 & -16.57 & 2373 & -10.86 \\
\hline 2019-2020* & 1889 & -11.06 & 598 & 11.36 & 2526 & -5.11 \\
\hline
\end{tabular}

Table 2. Change in production of cotton in Punjab, Sindh and Pakistan during from 1990-2020.

\begin{tabular}{ccccccc}
\hline \multirow{2}{*}{ Year } & \multicolumn{2}{c}{ Punjab province } & \multicolumn{2}{c}{ Sindh province } & \multicolumn{2}{c}{ Pakistan } \\
\cline { 2 - 7 } & Production & \% Change & Production & \% Change & Production & \% Change \\
\hline $1990-1991$ & 8501 & & 1125 & & 9627 & 33.2 \\
\hline $1991-1992$ & 11417 & 34.3 & 1403 & 24.7 & 12822 & -6.0 \\
\hline $1992-1993$ & 8237 & -3.1 & 816 & -27.5 & 9054 & -16.5 \\
\hline $1993-1994$ & 6523 & -23.3 & 1517 & 34.8 & 8041 & -9.7 \\
\hline $1994-1995$ & 7410 & -12.8 & 1282 & 14.0 & 8697 & 10.0 \\
\hline
\end{tabular}




\begin{tabular}{ccccccc}
\hline $1995-1996$ & 8720 & 2.6 & 1861 & 65.4 & 10594 & -2.6 \\
\hline $1996-1997$ & 7103 & -16.4 & 2250 & 100.0 & 9374 & -4.9 \\
\hline $1997-1998$ & 6817 & -19.8 & 2335 & 107.6 & 9152 & -9.0 \\
\hline $1998-1999$ & 6628 & -22.0 & 2134 & 89.7 & 8762 & 16.8 \\
\hline $1999-2000$ & 8804 & 3.6 & 2377 & 111.3 & 11240 & 11.5 \\
\hline $2000-2001$ & 8540 & 0.5 & 2141 & 90.3 & 10731 & 10.2 \\
\hline $2001-2002$ & 8046 & -5.4 & 2443 & 117.2 & 10612 & 6.1 \\
\hline $2002-2003$ & 7664 & -9.8 & 2413 & 114.5 & 10212 & 4.4 \\
\hline $2003-2004$ & 7702 & -9.4 & 2243 & 99.4 & 10048 & 48.2 \\
\hline $2004-2005$ & 11147 & 31.1 & 3017 & 168.2 & 14263 & 35.2 \\
\hline $2005-2006$ & 10268 & 20.8 & 2648 & 135.4 & 13019 & 33.5 \\
\hline $2006-2007$ & 10350 & 21.8 & 2398 & 113.2 & 12856 & 21.1 \\
\hline $2007-2008$ & 9062 & 6.6 & 2536 & 125.4 & 11655 & 22.8 \\
\hline $2008-2009$ & 8751 & 2.9 & 2978 & 164.7 & 11819 & 34.1 \\
\hline $2009-2010$ & 8552 & 0.6 & 4271 & 279.6 & 12914 & 19.0 \\
\hline $2010-2011$ & 7854 & -7.6 & 3537 & 214.4 & 11460 & 41.2 \\
\hline $2011-2012$ & 11129 & 30.9 & 2357 & 109.5 & 13595 & 35.3 \\
\hline $2012-2013$ & 9526 & 12.1 & 3400 & 202.2 & 13030 & 32.6 \\
\hline $2013-2014$ & 9145 & 7.6 & 3523 & 213.2 & 12768 & 45.0 \\
\hline $2014-2015$ & 10277 & 20.9 & 3573 & 217.6 & 13960 & 3.0 \\
\hline $2015-2016$ & 6343 & -25.4 & 3476 & 209.0 & 9918 & 10.8 \\
\hline $2016-2017$ & 6978 & -17.9 & 3597 & 219.7 & 10671 & 24.1 \\
\hline $2017-2018$ & 8077 & -5.0 & 3776 & 235.6 & 11946 & 2.4 \\
\hline $2018-2019$ & 6826 & -19.7 & 2938 & 161.2 & 9861 & -4.7 \\
\hline $2019-2020$ & 6336 & -25.5 & 2746 & 144.1 & 9178 & 33.2 \\
\hline
\end{tabular}

Table 3. Change in average yield of cotton in Punjab, Sindh and Pakistan from 1990-2020.

\begin{tabular}{lcccccc}
\hline \multirow{2}{*}{ Year } & \multicolumn{2}{c}{ Punjab province } & \multicolumn{2}{c}{ Sindh province } & Pakistan & \\
\cline { 2 - 7 } & Yield & \% Change & Yield & \% Change & Yield & \% Change \\
\hline $1990-91$ & 681 & & 356 & & 615 & \\
\hline $1991-92$ & 849 & 24.67 & 435 & 22.2 & 769 & 25.0 \\
\hline $1992-93$ & 574 & -15.71 & 349 & -2.0 & 543 & -11.7 \\
\hline $1993-94$ & 493 & -27.61 & 465 & 30.6 & 488 & -20.7 \\
\hline $1994-95$ & 562 & -17.47 & 537 & 50.8 & 558 & -9.3 \\
\hline $1995-96$ & 602 & -11.60 & 598 & 68.0 & 601 & -2.3 \\
\hline $1996-97$ & 476 & -30.10 & 636 & 78.7 & 506 & -17.7 \\
\hline $1997-98$ & 494 & -27.46 & 662 & 86.0 & - & \\
\hline $1998-99$ & 494 & -27.46 & 576 & 61.8 & - & \\
\hline $1999-2000$ & 643 & -5.58 & 637 & 78.9 & 641 & 4.2 \\
\hline $2000-2001$ & 608 & -10.72 & 695 & 95.2 & 624 & 1.5 \\
\hline $2001-2002$ & 541 & -20.56 & 759 & 113.2 & 579 & -5.9 \\
\hline
\end{tabular}




\begin{tabular}{lcccccc}
\hline $2003-2004$ & 549 & -19.38 & 680 & 91.0 & 572 & -7.0 \\
\hline $2004-2005$ & 753 & 10.57 & 808 & 127.0 & 760 & 23.6 \\
\hline $2005-2006$ & 720 & 5.73 & 707 & 98.6 & 714 & 16.1 \\
\hline $2006-2007$ & 714 & 4.85 & 715 & 100.8 & 711 & 15.6 \\
\hline $2007-2008$ & 635 & -6.75 & 710 & 99.4 & 649 & 5.5 \\
\hline $2008-2009$ & 669 & -1.76 & 901 & 153.1 & 713 & 15.9 \\
\hline $2009-2010$ & 597 & -12.33 & 1143 & 221.1 & 713 & 15.9 \\
\hline $2011-2012$ & 607 & -10.87 & 1316 & 269.7 & 724 & 17.7 \\
\hline $2012-2013$ & 747 & 9.69 & 1547 & 334.6 & 815 & 32.5 \\
\hline $2013-2014$ & 702 & 3.08 & 1091 & 206.5 & 769 & 25.0 \\
\hline $2014-2015$ & 752 & 10.43 & 1019 & 186.2 & 802 & 25.9 \\
\hline $2016-2016$ & 481 & -29.37 & 952 & 167.4 & 581 & 30.4 \\
\hline $2017-2018$ & 654 & -3.96 & 960 & 169.7 & 729 & 18.5 \\
\hline $2018-2019$ & 669 & -1.76 & 1049 & 194.7 & 752 & 22.3 \\
\hline $2019-2020$ & 515 & -9.69 & 1115 & 213.2 & 706 & 14.8 \\
\hline
\end{tabular}

Factors behind the change in area, production and Yield of the cotton in Pakistan

In this section different factors contributing to change in area, production and yield of cotton in Punjab, Sindh and Pakistan are explored. Scholarly articles were critically examined to consolidate those challenges which are regarded as the key impediments in lowering the production of cotton. Plenty of research studies have been conducted to unveil different challenges thus, the literature was further grouped into different sections such as (i) environmental constraints (ii) water management constraints (iii) agronomic constraints (iv), and socio-economic constraints. Under the environmental constraints, soil salinity and waterlogging, soil fertility depletion and climatic impacts are discussed.

\section{Environmental constraints}

\section{Soil Salinity and waterlogging}

Soil salinity refers to the state, when excessive salts accumulate inside the soil and adversely harm the physical, chemical and biological properties of the soil. Around the world, 831Mha was reported as salt affected. Of this total salt-affected area, 397 Mha was saline and 434 Mha was sodic (Hasanuzzaman et al., 2014). For Pakistan, 4.5Mha area was regarded salt affected (Aslam, 2016). Pakistan is an agrarian country where tube well irrigation is seen as more accessible. Due to saline ground water and use of poor-quality tube well water for irrigation purpose, the level of salinity surged (Qureshi et al., 2008). Findings were endorsed by the report of Pakistan Council of Science and Technology (2003), as the report found 70 percent of the tube wells of Indus basin impelled sodic or saline-sodic water. The total saline or saline sodic area reached to $2.3 \mathrm{Mha}$. This intense salinity had adverse impacts on growth of plants. Shahzad et al. (2019) confined that the escalated level of salinity accompanying the high electrical conductivity (EC) caused dehydration in plant cells, diminished the plant growth and sometimes the death of plants occurred particular those which were considerably less tolerant.

Salinity has direct adverse impacts on cotton plant growth process because of its moderate tolerance to salinity. The threshold level of cotton regarding salt tolerance was $7.7 \mathrm{dSm}^{-1}$ (Zhang et al., 2013). Soil salinity inversely influence the cotton yield, growth and fiber quality and pertaining to salt stress delayed flowering, less fruiting, fruit shedding and lessening in boll weight could occur eventually (Sharif et al., 2019). Salinity caused 50-90\% reduction in cotton yield (Ahmad et al., 2002; Khorsandi and Anagholi, 2009).

Cotton crop has poor waterlogging tolerance as well. Waterlogging can potentially reduce the growth and development process of the cotton and its quality, physiological metabolism and the yield at the end (Ashraf et al., 2011; Dodd et al., 2013). Flowering, seedling, 
squaring and boll-opening stages were influenced negatively by the waterlogging whereas the yield reduced inclusively. Waterlogging further negatively influenced the quality attributes of the cotton such as uniformity index, elongation, micronaire value, upper-half mean length yellowness and lint quality (Wang, Chen, et al., 2017). According to the findings of Zhang et al. (2021), waterlogging conditions reduced the oxygen level in soil, handicap the growth and development stages and led the crop to failure at the end by impairing and blocking the nutrient uptake (Milroy et al., 2009; Dodd et al., 2013; Guang et al., 2012; Najeeb et al., 2015).

\section{Soil fertility depletion}

Adequate nutrient-use efficiency is much needed for the plant to grow well. Thus, availability of required nutrients in the root zone of plant is obligatory and helpful for the plant to stand responsive (Havlin and Heiniger, 2020). In case of reduction of soil fertility, the production of the particular crop may go down. Hamid and Ahmad (2001) reported a low fertilizer use efficiency which reduced the soil fertility level further causing a drastic decline in crop production. They further identified that cultivation of crops one after the other depleted the nutrition from soil. Moreover, injudicious and imbalance use of fertilizer as being practices across the Pakistan further depleted the nutritional vigor of land. Solaiman and Ahmed (2006) reported an excessive application of Nitrogen $(\mathrm{N})$ quicker than for Phosphorous (P) or Potassium (K) as $\mathrm{P} \& \mathrm{~K}$ are often regarded as an expensive import. Pakistani soils are lacking in all three N, P \& K macro-nutrients. Being a less expensive use of $\mathrm{N}$ was high and it has increased the yields but yet the yield gap exists because of limited addition of P \& K (Solaiman and Ahmed, 2006). Pakistan was ranked fourth in terms of $\mathrm{N}$ use but low average yields of the crops (Shahzad et al., 2019).

Apart from these three macro-elements, almost two-third of agricultural soils in Pakistan were deficient in $\mathrm{Zn}$ (Rashid, 2005). A fertile soil and balanced availability of macro and micro-nutrients is obligatory for the cotton production and certain quality. Wakeel and Ishfaq (2016) found that majority of the soils $(67 \%)$ in cotton areas of Pakistan were deficient in $\mathrm{P}$ whereas farmers in the cotton growing areas were more inclined towards use of $N$ \& P whereas only $16 \%$ of farmers had the use of $K$ fertilizer. Cotton growers had inadequate awareness about the balanced use of fertilizers for the cotton (Mahmood et al., 2017). Cotton is considered highly inefficient in nutrients utilization in producing seed cotton yields (Malik, 1998). Thus, it is much needed for the farmers to sustain the soil fertility and ensure availability of required balanced fertilizers in root zone.

\section{Climatic impacts}

Cotton crop has ecstatic resilience level to high temperature and drought conditions because of its vertical tap root system. Cotton is perennial shrub that necessitates warm days and night for optimal growth and development. Boyer (1982) had reported that cotton was sensitive to fluctuating temperature and readiness of water at the flowering and boll formation stage. Pakistan is turning water scarce which may originate the delay in land preparation and delayed sowing of cotton which further lowered the number of bolls, dry matter, fiber quality and cottonseed yield (Arshad et al., 2021; Wang, Deng, et al., 2017; Wang et al., 2014). Abbas (2020) was of the view that increasing temperature in Pakistan was not increasing the production of cotton. Sowing of cotton, emergence, flowering and maturity stages were inversely correlated with the temperature. This implies that with the increase in temperature the yield of cotton was not promising.

There is more evidence that has reported an adverse impact of climate change on cotton crops. Iqbal et al. (2017) and Amin et al. (2018) agreed that cotton production declined due to climate change and cotton production management techniques appeared unproductive in wake of climate change (Zulfiqar and Thapa, 2018; Zulfiqar et al., 2017). According to the findings of Zhang et al. (2008) and Amin et al. (2018), owing to indeterminate growth patterns of cotton, the crop attains a composite set of fruits, which are regarded as extremely vulnerable to the erratic weather and eventually ending to production discrepancy.

\section{Water management constraints}

Water is a key element for the optimum growth of the cotton (Sahito et al., 2015). Cotton requires balanced irrigation to mature whereas excessive of inadequate irrigations can lower its production. Some studies such as Patel et al. (1995), El-Shahawy and Abd-El-Malik (2005) and Abd-El-Malak and Radwan (1998) found that growth and yield component of cotton were significantly influenced by the irrigation frequencies. The findings of the Sahito et al. (2015) had the same view that growth attributes and yield components of cotton were significantly associated with the frequency of irrigations. Adequate application of irrigation ensured enhanced boll formation and development (Ertek and Kanber, 2003). 
This implies that over irrigation in the cotton should be avoided (Abd-El-Malak and Radwan, 1998; Rajput, 2006; Enciso et al., 2003). These studies concluded that moderate level of water is adequate for the cotton whereas excessive application of water can hinder the growth parameters. Some more studies such as Makhdum (2011) and Nazli (2012) have reported that excessive irrigation applied by the farmers had negative impacts on the production of cotton in Pakistan. This excessive usage of water in cotton crop, excessive use of groundwater as most of the farmers use tube wells and deterioration of natural resources were not only influencing the cotton yield but also pressurizing the sustainability of the system (Watto and Mugera, 2015; Zulfiqar and Thapa, 2018; Zhu et al., 2013; Watto, 2013).

\section{Agronomic constraints}

Agronomic aspects are regarded important in the increased production of cotton. In case agronomic aspects are not understood well the production of cotton crop may face a drastic decline for many reasons. According to Ali et al. (2009) of the many agronomic aspects responsible for the low production of cotton, planting technique was the key. It helps the plant to grow well and offers a good crop stand and eventually ensuring the good production. Farmers in Pakistan are usually found practicing traditional methods of sowing cotton which earned them poor production. On contrary, the modern techniques could have given them the higher level of production. Boquet (2005) found that wider plant spacing in cotton crop gave an increase in number of bolls, increased boll weight and escalated lint yield. Whereas, in low plant density, Stephenson IV et al. (2011) found an optimum plant height, a greater number of monopodial and sympodial branches and an increase in number of bolls. Shahzad et al. (2019) recommended the sowing of cotton on $25 \mathrm{~cm}$ apart rows for the best fiber quality and more production.

Apart from the sowing technique, cotton production was influenced by the incidence of pests, outbreak of diseases, weeds infestation, soil salinity, degradation of soil, and development of herbicides resistance in weeds were other agronomic reasons behind the low production of cotton (Mollaee et al., 2019). In another study, Ali et al. (2019) have reported that insects pests attack was the main suppressor of cotton production and application of insecticides was the only way possible to control the insects' pests. They further explored that, non-availability of quality seed, diseases outbreak, heat and drought stress and unpredictable market prices were strong reasons behind poor production of cotton. Poor quality seed created germination problems and the plant coming out of soil remain week and stays susceptible to number of insects pests and diseases; ultimately leading to a hilarious crop failure (Atique ur et al., 2020). Fusarium wilt, boll rot, bacterial blight, leaf curl disease and Alternaria leaf spot were the common diseases contributing extensively in crop failure (Chohan et al., 2020). Forrester (2009) arbitrated that Pakistan lacks in professional seed industry, which is a mammoth factor hindering the production of cotton in Pakistan. Saeed et al. (2020) described that majority of seed growers in Pakistan didn't receive any formal training and vast majority didn't have the information regarding the safe storage and handling of the seed. While use substandard quality seed, not only the germination is influenced, but the cost of the production was also increased. Balaji and Kumar (2016) specifically highlighted that cost of production for the farmers was increased which cut their net profits. The report of Government of Pakistan (2019) reported the same findings that due to increased cost the benefits of farmers were compromised. In a study conducted by Raghavan (2008), he found that rise in input costs followed by erratic marketing and inadequate source for livelihoods hindered the cotton productivities.

\section{Socio-Economic constraints}

Socio-economic attributes of the farmers are augmented vital in the process of technological upscaling (Ahmad et al., 2021). Socio-economic conditions of the farmers had significant association with the cotton crop upscaling (Hashmi et al., 2016). They found that the size of the farm was statistically significant with the cotton crop production. In Pakistan, 1.6 million farmers were cotton growers. Whereas, $81 \%$ farmers are small landholders bearing average land less than 5.7 hectares (USDA, 2019). Contrary, the large farmers in Pakistan were reported as more influential and had more and easy access to the resources and the modern technology as reported by Kousar et al. (2017). On other hand, the small farmers had limited access to the services and resources they have were limited as well. This is worth mentioning that farmers decisions were associated with the access to resources, extension services (Nyairo et al., 2021), inputs availability, government support and affordability (USDA, 2019). Thus, the small farmers were unable to make decisions much needed to improve the cotton productivity. Non-availability of required information, 
high prices of inputs like pesticides, soil reclamation materials, organic manures, and poor technical knowledge aggravated the constraints and influenced the cotton production Gohil (2016). In another study, Raghavan (2008) rising input costs, sluggish marketing system and lack of sources to support livelihoods were barriers in wake of cotton production. Pertaining to many plights, farmers were ineffective in getting targeted yield of cotton. Financial limitations, exertion in accessing the credit, access to extension advisory services and inadequate level of formal education were factors suppressing the cotton yield (Wei et al., 2020). Saeed et al. (2020) found that farmers had lack of information regarding agricultural inputs (Hassan et al., 2021) and their use hindered farmers to prepare quality seed for the cotton crop. Number of research studies such as Makhdum (2011), Watto and Mugera (2015) and Zulfiqar and Thapa (2016) have reported that majority of the farming masses in Pakistan are still practicing traditional agriculture. Farmers are also producing cotton production through traditional production practices (using excessive inputs, high dose of fertilizers and excessive application of water for irrigation). Consequently, the cost of production has increased excessively, and resources use efficiency remained very low (Makhdum, 2011; Watto and Mugera, 2015; Zulfiqar et al., 2017).

\section{CONCLUSION AND RECOMMENDATIONS}

The economic value of the cotton crop for Pakistan is momentous and to facilitate the cotton led industry and the livelihoods of the farmers, the emergent need is to expedite the cotton production. The area, production and yield of the cotton in Punjab province and Pakistan is gradually changing inversely. The area has started to decline continuously and production is facing the same decline in Punjab province particularly. The average yield in the Punjab province has drastically declined. Whereas, In Pakistan, the area, production and yield are declining a well. This implies that Pakistan may become cotton scarce and dependence on imports will increase to run textile sector. From 2015, the change in area, production ad yield declined more severely. Environmental constraints especially climatic changes had more adverse impacts on the cotton production. However, the abrupt decrease in area under cotton cultivation turned the situation perplexed. The decline in production and yield of cotton can be associated with different agronomic, water related, environmental and socio-economic related constraints. The change is area is yet required to be explored that what reasons are behind causing the decline in area under cultivation. Possibility exists that pertaining to numerous constraints farmers have quit cotton cultivation or switched to other crops. This is suggested that further studies are required to critically examine the reasons of change in area under cotton cultivations. Moreover, the reasons should be explored that why farmers have quit cotton cultivation and what factors are compelling farmers to switch to other crops.

\section{CONFLICT OF INTEREST}

The authors declare that they have no conflicts of interest.

\section{REFERENCES}

Abbas, S. 2020. Climate change and cotton production: an empirical investigation of Pakistan. Environmental Science and Pollution Research, 27: 29580-88.

Abd-El-Malak, K. and F. Radwan. 1998. The proper irrigation intervals for vegetative and fruiting stages of cotton cultivar Giza 83. Egyptian Journal of Agricultural Research (Egypt).

Abid, M., M. Ashfaq, S. Hassan and N. Fatima. 2011. A resource use efficiency analysis of small Bt cotton farmers in Punjab, Pakistan. Pak. J. Agric. Sci, 48: 65-71.

Ahmad, S., M. Z. Iqbal, A. Hussain and M. Hassan. 2002. Salt tolerance of cotton (Gossypium hirsutum L.). Asian Journal of Plant Sciences.

Ahmad, T. I., R. E. Khan, M. A. Soharwardi, M. N. Shafiq and S. Gillani. 2021. Socioeconomics and agronomy of wheat yield in cotton-wheat cropping system in Punjab, Pakistan: A quality-quantity assessment. International Journal of Agricultural Extension, 9: 69-78.

Ali, A., M. Tahir, M. Ayub, I. Ali, A. Wasaya and F. Khalid. 2009. Studies on the effect of plant spacing on the yield of recently approved varieties of cotton. Pak. j. life soc. sci, 7: 25-30.

Ali, H., H. Ali, Z. Faridi and H. Ali. 2013. Production and forecasting trends of cotton in Pakistan: An analytical view. Journal of Basic and Applied Scientific Research, 3: 97-101.

Ali, M. A., J. Farooq, A. Batool, A. Zahoor, F. Azeem, A. Mahmood and K. Jabran. 2019. Cotton Production in Pakistan. Wiley. Place Published. pp.249-76.

Ali, S., N. Badar and H. Fatima. 2015. Forecasting 
production and yield of sugar cane and cotton crops of Pakistan for 2013-2030. Sarhad Journal of Agriculture, 31: 1-10.

Amin, A., W. Nasim, M. Mubeen, A. Ahmad, M. Nadeem, P. Urich, S. Fahad, S. Ahmad, A. Wajid, F. Tabassum, H. M. Hammad, S. R. Sultana, S. Anwar, S. K. Baloch, A. Wahid, C. J. Wilkerson and G. Hoogenboom. 2018. Simulated CSM-CROPGRO-cotton yield under projected future climate by SimCLIM for southern Punjab, Pakistan. Agricultural Systems, 167: 21322.

Arshad, A., M. A. Raza, Y. Zhang, L. Zhang, X. Wang, M. Ahmed and M. Habib-ur-Rehman. 2021. Impact of Climate Warming on Cotton Growth and Yields in China and Pakistan: A Regional Perspective. Agriculture, 11: 97.

Ashraf, M. A., M. S. A. Ahmad, M. Ashraf, F. Al-Qurainy and M. Y. Ashraf. 2011. Alleviation of waterlogging stress in upland cotton (Gossypium hirsutum L.) by exogenous application of potassium in soil and as a foliar spray. Crop and Pasture Science, 62: 25.

Ashraf, S., A. H. Sangi, Z. Y. Hassan and M. Luqman. 2018. Future of cotton sector in Pakistan: A 2025 Outlook. Pakistan Journal of Agricultural Research, 31.

Aslam, M. 2016. Agricultural productivity current scenario, constraints and future prospects in Pakistan. Sarhad Journal of Agriculture, 32: 289303.

Atique ur, R., M. Kamran and I. Afzal. 2020. Production and Processing of Quality Cotton Seed. Springer Singapore. Place Published. pp.547-70.

Balaji, S. and S. Kumar. 2016. Constraints in Cotton Cultivation: Cost Issues and Options for Income Increments. Indian Journal of Agricultural Economics, 71: 361-73.

Boquet, D. J. 2005. Cotton in ultra-narrow row spacing: Plant density and nitrogen fertilizer rates. Agronomy Journal, 97: 279-87.

Boyer, J. S. 1982. Plant Productivity and Environment. Science, 218: 443-48.

Chohan, S., R. Perveen, M. Abid, M. N. Tahir and M. Sajid. 2020. Cotton Diseases and Their Management. Springer Singapore. Place Published. pp.239-70.

Dodd, K., C. Guppy, P. V. Lockwood and I. J. Rochester. 2013. Impact of waterlogging on the nutrition of cotton (Gossypium hirsutum L.) produced in sodic soils. Crop and Pasture Science, 64: 816-24.
El-Shahawy, M. and R. Abd-El-Malik. 2005. Response of Giza 87 Cotton Cultivar Gossypium barbadense L. to Irrigation Intervals and Nitrogen Fertilization Levels. Egyptian Journal of Agricultural Research, 77: 841-56.

Enciso, J. M., B. L. Unruh, P. D. Colaizzi and W. L. Multer. 2003. Cotton response to subsurface drip irrigation frequency under deficit irrigation. Applied Engineering in Agriculture, 19.

Ertek, A. and R. Kanber. 2003. Effects of different drip irrigation programs on the boll number and shedding percentage and yield of cotton. Agricultural Water Management, 60: 1-11.

Forrester, N. 2009. Changing the Cotton Landscape in Pakistan." Lahore: Ali Tareen Farms. Place Published.

Gohil, G. 2016. Constraints Faced by Cotton Growers in Crisis Management of Cotton Cultivation in Gujarat. International Journal of Agriculture Sciences: 0975-3710.

GOP. 2019. Economic Survey of Pakistan. Finance Divisions, Islamabad, Pakistan. Place Published.

Guang, C., W. Xiugui, L. Yu and L. Wenbing. 2012. Effect of Water Logging Stress on Cotton Leaf Area Index and Yield. Procedia Engineering, 28: 202-09.

Hamid, A. and N. Ahmad. 2001. Integrated Plant Nutrient System: Development and Rural Poverty Alleviation. In: Regional Workshop on Integrated Plant Nutrient System Development and Rural Poverty Alleviation 2001, Bangkok, Thailand, 1820 September. Place Published.

Hasanuzzaman, M., K. Nahar, M. Alam, P. C. Bhowmik, M. Hossain, M. M. Rahman, M. N. V. Prasad, M. Ozturk and M. Fujita. 2014. Potential use of halophytes to remediate saline soils. BioMed research international, 2014.

Hashmi, M., M. Kamran, K. Bakhsh and M. Bashir. 2016. Role of socio-economic factors on scale efficiency of cotton farms. Bulgarian Journal of Agricultural Science, 22: 358-67.

Hassan, G., I. Ashraf, N. U. Hassan, M. Ali, I. Khalid, E. Ashraf, H. Raza, R. T. Husnain and S. Asghar. 2021. Information deficiency among farmers regarding vegetable production practices in peri-urban areas of the Punjab-Pakistan. International Journal of Agricultural Extension, 9: 19-28.

Havlin, J. and R. Heiniger. 2020. Soil Fertility Management for Better Crop Production. Agronomy, 10: 1349. 
Iqbal, M., S. Ul-Allah, M. Naeem, M. Ijaz, A. Sattar and A. Sher. 2017. Response of cotton genotypes to water and heat stress: from field to genes. Euphytica, 213.

Khorsandi, F. and A. Anagholi. 2009. Reproductive compensation of cotton after salt stress relief at different growth stages. Journal of Agronomy and Crop Science, 195: 278-83.

Kousar, S., P. S. U. Sabri, M. Zafar and A. Akhtar. 2017. Technological factors and adoption of green innovation: moderating role of government intervention: a case of SMEs in Pakistan. Pakistan Journal of Commerce and Social Sciences (PJCSS), 11: 833-61.

Makhdum, A. H. K., H.N.; Ahmad, S. 2011. Reducing cotton footprints through implementation of better management practices in cotton production; a step towards better cotton initiative. In Proceedings of the Fifth Meeting of the Asian Cotton Research and Development Network, Lahore, Pakistan, 23-26 February 2011; pp. 1-18. Available online: https://www.icac.org/tis/regional networks/asia n network/meeting 5/ (accessed on 4 January 2018). Place Published.

Malik, M. 1998. Fertilizer Role in Sustainable Cotton Production. Place Published. pp.20-29.

Milroy, S. P., M. P. Bange and P. Thongbai. 2009. Cotton leaf nutrient concentrations in response to waterlogging under field conditions. Field Crops Research, 113: 246-55.

Mollaee, M., A. Mobli, N. K. Mutti, S. Manalil and B. S. Chauhan. 2019. Challenges and Opportunities in Cotton Production. Wiley. Place Published. pp.37190.

Najeeb, U., M. P. Bange, D. K. Y. Tan and B. J. Atwell. 2015. Consequences of waterlogging in cotton and opportunities for mitigation of yield losses. AoB PLANTS, 7: plv080.

Nazli, H. O., D.; Sarker, R.; Meilke, K. 2012. Bt Cotton Adoption and Wellbeing of Farmers in Pakistan. In Proceedings of the International Association of Agricultural Economists (IAAE) Triennial Conference, Foz do Iguaçu, Brazil, 18-24 August 2012; pp. 1-26. Available online: ageconsearch.umn.edu/bitstream/ 126172/ (accessed on 3 February 2018). Place Published.

Nyairo, N. M., L. J. Pfeiffer and M. Russell. 2021. Smallholder farmers' perceptions of agricultural extension in adoption of new technologies in
Kakamega County, Kenya. International Journal of Agricultural Extension, 9: 57-68.

Pakistan Council of Science and Technology. 2003. Report of national committee on water resources development and management. Pakistan Council of Science and Technology, Government of Pakistan, Islamabad, Pakistan. Place Published.

Patel, P., D. Patel and U. Patel. 1995. Response of cotton G. Cot Hy. 8 to irrigation based on IW/CPE ratio. Gujarat Agricultural University Research Journal, 20: 143-45.

Qureshi, A. S., P. G. McCornick, M. Qadir and Z. Aslam. 2008. Managing salinity and waterlogging in the Indus Basin of Pakistan. Agricultural Water Management, 95: 1-10.

Raghavan, M. 2008. Changing pattern of input use and cost of cultivation. Economic and Political Weekly: 123-29.

Rajput, H. A. 2006. Effect of Different Irrigation Regimes on the Performance of Different Cotton Cultivars. Master's Thesis, Sindh Agriculture University, Tandojam. Place Published.

Rashid, A. 2005. Establishment and management of micronutrient deficiencies in soils of Pakistan: A review. Soil Environ, 24: 1-22.

Saeed, M. F., A. Jamal, I. Ahmad, S. Ali, G. M. Shah, S. K. Husnain, A. Farooq and J. Wang. 2020. Storage Conditions Deteriorate Cotton and Wheat Seeds Quality: An Assessment of Farmers' Awareness in Pakistan. Agronomy, 10: 1246.

Sahito, A., Z. A. Baloch, A. Mahar, S. A. Otho, S. A. Kalhoro, A. Ali, F. A. Kalhoro, R. N. Soomro and F. Ali. 2015. Effect of water stress on the growth and yield of cotton crop (Gossypium hirsutum L.). American Journal of Plant Sciences, 6: 1027.

Shahzad, A. N., M. K. Qureshi, A. Wakeel and T. Misselbrook. 2019. Crop production in Pakistan and low nitrogen use efficiencies. Nature Sustainability, 2: 1106-14.

Sharif, I., S. Aleem, J. Farooq, M. Rizwan, A. Younas, G. Sarwar and S. M. Chohan. 2019. Salinity stress in cotton: effects, mechanism of tolerance and its management strategies. Physiology and Molecular Biology of Plants, 25: 807-20.

Shuli, F., A. H. Jarwar, X. Wang, L. Wang and Q. Ma. 2018. Overview of the cotton in Pakistan and its future prospects. Pakistan Journal of Agricultural Research, 31: 396. 
Solaiman, S. and N. Ahmed. 2006. Improving Plant Nutrient Management for Better Farmer Livelihoods. Food Security and Environmental Sustainability.

Stephenson IV, D. O., L. T. Barber and F. M. Bourland. 2011. Effect of twin-row planting pattern and plant density on cotton growth, yield, and fiber quality. Journal of Cotton Science, 15: 243-50.

Tunio, A., H. Magsi and M. A. Solangi. 2016. Analyses of growth trends and production forecast of cash crops in Pakistan. International Journal of Agronomy and Agricultural Research, 9: 158-64.

USDA. 2019. U.S. Department of Agriculture . Pakistan cotton and products annual 2019 (C., Bean , Ed.). Global Agriculture Information Networks, USDA Foreign agriculture services. Place Published.

Wakeel, A. and M. Ishfaq. 2016. Promoting precise and balanced use of fertilizers in Pakistan at farm-gate level. Electronic International Fertilizer Correspondent (e-ifc): 20-25.

Wang, X., Z. Deng, W. Zhang, Z. Meng, X. Chang and M. Lv. 2017. Effect of Waterlogging Duration at Different Growth Stages on the Growth, Yield and Quality of Cotton. PloS one, 12: e0169029.

Wang, X., L. Zhang, J. B. Evers, L. Mao, S. Wei, X. Pan, X. Zhao, W. van der Werf and Z. Li. 2014. Predicting the effects of environment and management on cotton fibre growth and quality: a functionalstructural plant modelling approach. AoB PLANTS, 6: plu040-plu40.

Wang, Z., J. Chen, F. Xing, Y. Han, F. Chen, L. Zhang, Y. Li and C. Li. 2017. Response of cotton phenology to climate change on the North China Plain from 1981 to 2012. Scientific Reports, 7.

Watto, M. 2013. Measuring Groundwater Irrigation Efficiency in Pakistan: A DEA Approach Using the Sub-vector and Slack-based Models. In Proceedings of the 57th Australian Agricultural and Resource Economics Society Annual Conference, Sydney, Australia, 5-8 February 2013; pp. 1-35. Place Published.
Watto, M. A. and A. W. Mugera. 2015. Econometric estimation of groundwater irrigation efficiency of cotton cultivation farms in Pakistan. Journal of Hydrology: Regional Studies, 4: 193-211.

Wei, W., Z. Mushtaq, A. Ikram, M. Faisal, Z. Wan-Li and M. I. Ahmad. 2020. Estimating the economic viability of cotton growers in Punjab Province, Pakistan. SAGE Open, 10: 2158244020929310.

Zhang, L., W. van der Werf, S. Zhang, B. Li and J. H. J. Spiertz. 2008. Temperature-mediated developmental delay may limit yield of cotton in relay intercrops with wheat. Field Crops Research, 106: 258-68.

Zhang, L., G. Zhang, Y. Wang, Z. Zhou, Y. Meng and B. Chen. 2013. Effect of soil salinity on physiological characteristics of functional leaves of cotton plants. Journal of Plant Research, 126: 293-304.

Zhang, Y., G. Liu, H. Dong and C. Li. 2021. Waterlogging stress in cotton: Damage, adaptability, alleviation strategies, and mechanisms. The Crop Journal, 9: 257-70.

Zhu, T., C. Ringler, M. M. Iqbal, T. B. Sulser and M. A. Goheer. 2013. Climate change impacts and adaptation options for water and food in Pakistan: scenario analysis using an integrated global water and food projections model. Water International, 38: 651-69.

Zulfiqar, F., A. Datta and G. B. Thapa. 2017. Determinants and resource use efficiency of "better cotton": An innovative cleaner production alternative. Journal of Cleaner Production, 166: 1372-80.

Zulfiqar, F. and G. B. Thapa. 2016. Is 'Better cotton' better than conventional cotton in terms of input use efficiency and financial performance? Land Use Policy, 52: 136-43.

Zulfiqar, F., and Thapa, G. B. (2018). Determinants and intensity of adoption of "better cotton" as an innovative cleaner production alternative. Journal of cleaner production, 172, 3468-3478.

Publisher's note: EScience Press remains neutral with regard to jurisdictional claims in published maps and institutional affiliations.

Open Access This article is licensed under a Creative Commons Attribution 4.0 International License. To view a copy of this license, visit http://creativecommons.org/licenses/by/4.0/. 